\title{
AUDIOVISUALITY AND THE CITY OF MARSEILLE, FRANCE: CREATIVITY, COMMUNICATION, REPRESENTATION
}

\author{
Dario MARTINELLI* \\ Vilnius Gediminas Technical University, Faculty of Creative Industries, \\ Department of Entertainment Industries, Traku str. 1, LT-01132, Vilnius, Lithuania
}

Received 11 September 2018; accepted 5 April 2019

\begin{abstract}
The Wicked City (director Peter Mak, 1992), House on the Waterfront (director Edmond T. Gréville, 1955), The French Connection (director William Friedkin, 1971), the obvious Borsalino (director Jacques Deray, 1970)... up to the recent Netflix series Marseille (creator Dan Franck, 20162018): when browsing the titles of the most important audiovisual representations of Marseille, one immediately notices how this city seems to (be made to) communicate a few recurrent topoi: the frontier city, site of mostly illegal activities and inhabited by a multi-ethnic (or rather stateless) community of gangsters, sailors, adventurers and prostitutes - ingredients often mixed with an abundant amount of charm and nostalgic fascination. Mostly informed by the theories and methodologies of film studies, musicology, creativity studies and communication studies, the present article aims to emphasize the consistence of significations conveyed by both visual and musical sources. As a case-study, the article shall focus on Borsalino, possibly - at the same time - the most famous film placed in Marseille and the most famous soundtrack (by jazz composer Claude Bolling) - both, it is argued, perfect syntheses of the above-mentioned topoi.
\end{abstract}

Keywords: audiovisual communication, Borsalino, Marseille, musicology, film music, film studies, semiotics.

\section{Introduction}

As already suggested in recent studies (e.g., Martinelli, 2010, pp. 11-50, 2016, pp. 89-128), the question of authenticity in popular culture can be contextualized in six different and not mutually-exclusive manners: geography, history, economy, performance, style and rhetoric. The "authentication" of a given entity, that is, the particular process that (for justifiable reasons or not) assigns the status of authenticity by combining and systematizing a number of features and values in a relatively-coherent manner (in other words, ideologizing the entity), becomes particularly interesting and organic when that entity is a "city". First, because that process necessarily needs to engage in all the six mentioned contextualizations, not only the predictable "geography" (which however remains in the foreground), creating a rich network

${ }^{\star}$ Corresponding author. E-mail: dario.martinelli@vgtu.lt 
of relations among the various elements involved; and second, because the outcomes of the process come to form a set of cultural and mythical topoi that more often than not constitute the very essence of that city's image and soft power.

This is certainly true when the popular culture items one focuses on and operate within audiovisual (particularly musical and filmic) creativity. A city like Naples, Italy, for instance, offers a perfect example of a geographical place whose cultural and mythical image is profoundly related to music: although I say this with no statistical support, there is every chance that if we ask a sample of people to associate Naples with the first few things that come to their mind, at least one or two of those things will turn out to be music-related: "O sole mio" (written in 1898), the mandolin, Enrico Caruso, the idea itself of singing (and of the people who like singing), and so forth. The threshold between authentication and stereotypization is of course very subtle, if there is any threshold at all, but that is certainly part of the controversial aspects of a notion like authenticity (something that I explicitly dealt with, and rather critically, in the two references mentioned).

What happens if that city is Marseille? How does that above-mentioned combination/systematization of features and values function, and what are the communicative results? What are the audiovisual topoi of Marseille? Are they "authentic"? Or rather: did any authentication occur? This article aims to emphasize the consistence of significations conveyed by the filmic representations of Marseille, with a particular focus on the way the music contained in them contributes to the process and/or adds significations of its own. The reason for choosing this particular city is exactly related to a certain representational ambivalence: on the one hand, the presence of rather distinctive audiovisual topoi (criminality, illegality, escape, multi-ethnicity will be among the most recurrent ones, as we shall see); on the other hand (and we shall see that too) the absence of cultural markers comparable to those that for instance we have seen for Naples, or other cities that are recognizable at both levels: the general cultural perception/authentication/stereotypization, and the way these processes show up in audiovisual creative communication.

This particular ambivalence crosscuts with another one, that - to my mind - also affirms the value of this kind of study within the context of cultural studies. I am talking about Kevin A. Lynch's concept of "imeageability" of a city (1960). According to Lynch, the image of a city is a sentimental combination between an objective image and more subjective individual perceptions, in a two-way process between the human observer and the observed urban space. The observer selects, organizes, and gives sense to what s/he sees, and that may make the city's specific image as something altogether different from each different perspective of the various potential observers. When this interfacing process meets another mediation (the audiovisual one, in our case), the network of perceptions and projections becomes even more dense and texturized. This two levels of complexity, hopefully, will emerge in the present analysis.

To the best of my knowledge, a complete list of the films located in Marseille has not been compiled yet. However, partly browsing through the web and partly using the very useful Marcelline Block (2013, p. 128), there are about 120 titles within mainstream cinema that are worth of attention, and those shall form the analytical corpus of this article. In such amount there may also be cases where the location is not the real Marseille, but a recreation of it 
(in studios or elsewhere - I have not made a specific inquiry in this sense), while for sure we find cases where the appearance of the city is not stable for most of the film's duration, but simply temporary, as in movies like The Bourne Identity (director Doug Liman, 2002) or Love Actually (director Richard Curtis, 2003). Also, for the purposes of this article, I included two television series (TVSs), Plus belle la vie (creator and producer Hubert Besson, 2004-2018) and Marseille. The reason for this choice is due mostly to the centrality of Marseille in the respective stories, but also to the fact that - especially in the last twenty years or so (arguably since David Lynch's Twin Peaks (1990-1991, 2017)) - the artistic boundary between film and TVSs has gown thinner and thinner, making the latter by no means second-rate material to analyze.

Worthwhile to note is also the fact that, besides an obvious majority of French productions in this bunch, the rest of them tend to be American or Italian (or Franco-Italian, as in the famous case of Borsalino, object of this article's analysis later on).

\section{Crime, transition, nostalgia}

To engage directly into the main thesis defended in this article, I took the list of movies assembled and performed a simple selection: I removed all the titles whose plots stage situations of criminality and illegalities of sorts. What remained after this skimming was not more than thirty-odd titles, about one quarter of the total. And the amount could have grown even thinner, if I had counted those movies that are actually adaptations and remakes from previous titles or other media, as in the relevant case of Marcel Pagnol's theatre trilogy Marius (1931), Fanny (1932) and César (1936) (see Prime 2013 for a specific discussion on these particular films), which has been adapted and re-adapted for cinema several times. It seems evident, thus, that in the very majority of the cases, when a screenwriter or a director choose to locate their film in Marseille, it is because they intend to stage a story where illegality and/ or immorality, crime, violence and similar themes are at least significant, when not central.

Whether justified historically or constructed culturally, the intimate, "natural" connection between (creative representations of) Marseille and criminality is quite undeniable. There is no better way to describe that than the words employed by Olivier Bohler to explain the reason why Jean-Luc Godard's Breathless (1960) begins in Marseille:

"Facing the Vieux-Port, Michel Poiccard (Jean-Paul Belmondo), with his accomplice, a brunette, steals a car. Inside is a revolver, with which he will kill a policeman, sealing his destiny. In what other French city would an anonymous driver casually leave a weapon in his car? If Godard's film began in Paris, no one would have believed it" (Bohler, 2013, p. 49).

Getting a closer and more attentive look at the 120 titles examined, this central theme can be articulated in five main topical areas (genres, to an extent), together or separately. Let us list them in order of recurrence. First and foremost, crime, violence and illegality in a strict, direct, sense: texts about crime, rather than simply featuring it. These cases form the relative majority of the texts analyzed. Gangsters, thieves, organized crime, outlaws of all sorts seem to be the most frequent characters in Marseille stories (a few topical examples are discussed in Bohler, 2013). 
Secondly, we find what we may call "Harbor/frontier topics". Due to its history and (deserved or not) reputation of a not-too-safe port city, Marseille often serves as context for stories of adventurers, sailors, desperados and renegades, who are often escaping from the law (or - more existentially - from their past), due to their involvement in some illegal activity. A significant example of the blend between the themes of frontier and criminality is Maurice Tourneur's 1935 film Justin de Marseille, with its abundance of foreign and travelling characters, often involved in illegal activities: Eastern merchants, Chinese opium dealers, African immigrants, sailors, the Italian gangster Esposito, and so forth. For reasons probably best explained by millennia of discriminatory stereotyping of the gender roles, these characters tend quite invariably to be men, not women. If a woman is "illegal", she is usually a prostitute (we shall return to this later). Exactly the above-mentioned Pagnol's trilogy (and its audiovisual adaptations) can serve as practical illustration of this patriarchal distinction: the character of Marius is a sailor, the character of Fanny sells cockles outside a bar (cockles - I shall add - being the closest metaphor to a "stable home" that sea can offer). The two fall in love, but what eventually separates them is the sea itself, the seduction of adventure that Marius just cannot resist. The significance of Marseille's harbor area as film location is described at length in Jean-Luc Lioult 2013.

Thirdly, we have stories involving immigrant characters, North African (NA)/Muslim and Italian ones in particular. Marseille is notoriously a multi-ethnic city with a very crowded community of people from abroad, with a special prevalence of the former French colonies, particularly those from the NA area, and of course the nearby countries, Italy especially. With that in mind, once more, the roles assigned to many of these characters display little or no compatibility with morality and/or legality. In this case, too, a look at the ever-too-slow history of human civil progress may help explaining why "black" characters hardly get assigned leading (good or villain) roles. The list of movies involving immigrants in general, and North Africans (NAs)/Muslims in particular is very long: some of the most important titles were mentioned and discussed in Henri-Simon Blanc-Hoàng 2013 and include The Italian (director Olivier Baroux, 2010), Mother (director Henri Verneuil, 1992) and its sequel 588 rue paradis (director Verneuil, 1992), Bella Ciao (director Stéphane Giusti, 2001), Where the Heart Is (director Robert Guédiguian, 1998), The Town is Quiet (director Guédiguian, 2000), the Pay-Off (director Luc Besson, 2013) and the Taxi sagas (director Besson, 1998, 2000, 2003, 2007, 2018), and others.

Fourthly, there are love stories of the "cursed" (and again illegal, one way or another) type. Romance in Marseille is hardly easy or happy, even when it is communicated through lighter tones (with hints of the "comic relief" type, such as François Capella and Siffredi's fistfight over the prostitute Lola, in Borsalino). These love stories have most of the times a tragic element, and usually happen within the context of crime, betrayal and unaccomplishment. As already mentioned, while the prototypical male character is either an adventurer or a criminal, the recurrent "illegal business" assigned to the woman is prostitution.

Finally, Marseille has been also employed as setting for war movies, particularly World War II (WWII) movies. Though a far rarer occurrence than the other four of the present list, this particular topic opens up to a thematic treatment that, as discussed later, has a certain pertinence also to the other topics: the "good illegality". War movies of this kind, indeed (one 
may for instance think of Michael Curtiz’s 1944 classic Passage to Marseille), tend to focus on the underground, clandestine resistance of French partisans against Nazi occupation and interaction with/support to the Anglo-American allies. Thus, while communicating undisputable moral virtue (especially since the enemy is the archetypical villain Adolf Hitler), these characters, too, are in their own way "illegal", operating in ways that are clearly distant from "canonic" soldiers fighting in uniform on the battlefield.

These five "genres" can be framed within a few thematic/narrative contexts that seem to recur more often than others. The theme of the traumatic escape and/or difficult return is one we find particularly often. In numerous works, especially those pertaining the first four of the genres above mentioned, the main characters are "on the run" to or from (occasionally "through") Marseille, for whatever reason (again: illegal ones occurring most often), and the film documents their problematic relation with a city that may have rejected/harmed/ deceived them. Not rarely, and quite importantly, this relation is mediated by memory and awareness of the past: in one form or another, indeed, the "past" constitutes another significant element, and quite definitely the most typical "temporal mode" (concretely or symbolically) associated to Marseille.

Also intriguing is the fact that this city is most of the times a lo-tech one. Exactly due to this fascination for the past, Marseille is never characterized as a highly technological, innovative or "state of the art" place, unlike, for instance, the likes of Tokyo, New York, Hong Kong or London, which are often represented as modern business, political or social environments. When the hero of some action movie breaks through the headquarters of, say, the Chinese mafia or some American corrupt politician, that usually happens at the top of a fully-accessorized and stylish skyscraper. In Marseille, it is more likely that the same type of situation occurs in some bar or harbor's warehouse, with the gangster sitting on a simple wooden chair, instead of a designer's office sofa. Cars, weapons, clothes and all the rest tend to follow the same pattern.

Socially speaking, there is also a tendency to represent Marseille as a working class city, for the better and for the worse. With all the due exceptions, of course, a significant percentage of both heroes and villains, as well as main and side characters, belong to the less privileged classes of the Marseille society, and operate within a social space that is much more referable to them than to middle or upper class (harbors, bars, brothels, less wealthy districts, small houses, etc.). Crime as such, too, can be driven by need or desire to climb up the social ladder, rather than by greed or power.

Also, the creative shaping of crime and illegality tends very often to verge into the "romanticized". Due to some of the characteristics mentioned (fascination for the past, escapism, focus on the less privileged social classes), plus others we shall emphasize later, the staging of crime and criminals is very often subject to a sympathetic treatment. Films set in Marseille abound in "adorable scoundrels", "handsome loners", "bad guys with a heart of gold", and so forth.

As a harbor city, but also as a spot (we have seen it) suspended between present and past and between good and evil, Marseille often communicates a sense of instability and transition. Characters hardly "inhabit" or "settle" in this city: they rather arrive, return, leave (or dream of leaving), stay temporarily. Also existentially, there is often a feeling of precariousness, fatalism and out-of-timeness. It is perhaps no coincidence that the most popular saga 
located in Marseille, Taxi, with five installments and even an American remake, is exactly centered around a type of vehicle that hosts short and "temporary" journeys (not to mention that this saga, too, comprises stories of criminality, but we should not be surprised anymore, at this point).

\section{Musical strategies}

Given the presence of so many recurrent stylistic and thematic items, one would expect that Marseille, like most other cities with equally-strong characteristics, would qualify also for a musical (stereotyped) authentication, that is, for the establishment of one or more musical topo $i$ that, in time, people would unmistakably associate to the city, receiving a distinguished "flavor" of it. In the same way as, for instance, Los Angeles can be quickly evoked by surf music, Paris by the employment of a musette, Shanghai by a guzheng that particularly insists on the sixth grade of a major scale, and so forth, one would expect Marseille to be similarly evocable by a given rhythm or a given instrument. Yet, no, when one analyzes the soundtracks (main themes in particular) of the various films, there seems to be no particular topos that one may directly associate to the city as such. What we instead find is an array of topoi and colors that relate to the creative contexts of each movie, in terms of their historical placing, production (especially in the geographic sense: significant musical changes occur between American and French productions, for instance), genre conventions and individual paradigm of each film composer involved. In simpler words, it is not a case of a given film sounding "like Marseille", but it is rather Marseille sounding like a given film. Save the few exceptions here and there, three factors emerge more than others, in this respect. The first and most important concerns the creative conventions dictated by this or that musical genre and/or this or that historical/geographical context. For example, Max Steiner's celebrated soundtrack for Curtiz's war movie Passage to Marseille is a rather ideal combination of the two variables. On the one hand, it falls perfectly into the cliché of the early Hollywood film music aesthetics, which, as it has been repeated many times, "practically ordained late Romantic symphonic music as the unavoidable model" (Schweinhardt \& Gall, 2014, p. 137). On the other hand, the dynamic, stereotypically-masculine, adventurous, tense and occasionally threatening, epic and intensely dramatic nature of the overall musical "package" (composition, arrangement, performance, etc.) is a textbook case for "war film music" of the first half of the 20th century (changes started occurring from the late 1960's onwards, but definitely 1944 was in the thick of this particular aesthetics).

Needless to say, similar observations can be made not only about whole soundtracks but also about specific themes or songs: an excellent instance, here, would be the theme-song "Fanny", written by Harold Rome for the 1954 eponymous Broadway musical, adapted to the screen in 1961. In this case, as we are talking about a song for a romantic musical drama, the nod is mostly to Tin Pan Alley ballads and in general "stage musical" numbers (not forgetting that Rome had been a composer for Broadway since the 1930's).

In this sense, more than anything else, the "sound of Marseille" is the general sound of the genres it is represented within. 
But there is more. Some particular musical genres acquired a certain importance outside the film business, and then ended up being relevant for film music as well. In the case of France and French productions, one outstanding example (which will also serve us for the case study of this essay) is the emergence of new trends in jazz music from the late 1950's onwards (see Yanow, 2004 for an extensive, albeit too Hollywood-centric, historical account on the subject).

Following milestones such as the works of Duke Ellington for Anatomy of a Murder (director Otto Preminger, 1959) or Miles Davis for Ascenseur Pour Léchafaud (1958, a French production, significantly), genres like late bebop, cool jazz, free jazz and - a few years later - fusion became increasingly important ingredients within the overarching reform in philosophy, experimentation, narrativity and authorial creativity that the film industry was undergoing during the 1960's. Besides its own merits and characteristics, jazz became instrumental in nurturing that sense of narrative instability, characters' ambiguity and postmodern fragmentation that schools like Nouvelle Vague (origin: Paris, France, 2003) were programmatically pursuing.

The first consistent appearance of modern jazz in a production related to Marseille dates 1965, with a Franco-Italian noir called Je vous salue, Mafia! (director Raoul Lévy, 1965). Possibly due to the B-rated (some might say "cult") status of this movie, its truly remarkable soundtrack went almost unnoticed: its author was Hubert Rostaing, perhaps best known as the clarinettist and saxophonist in Django Reinhardt's quintet.

Jazz will have more than one opportunity to be in the spotlight, including what, to this day, have to be the two most noted Marseille-located films: The French Connection, with the masterfully eclectic fusion soundtrack scored by Don Ellis, and of course our case study Borsalino, which paradoxically winks much more to pre-bebop jazz, with an intentionally nostalgic atmosphere that fit both the movie and the artistic program of the film composer Bolling.

A third important element is the more predictable "ethnic" one, with a particular reference to NA musical cultures. Although it does not - evidently - characterizes Marseille in particular, such musical color is the closest thing to an attempt to promote a form of musical aesthetics that relates directly to the city represented. In this case, a significant example comes from the recent TVSs Marseille, whose soundtrack was composed by the two-time Academy Awards winner Alexandre Desplat, one of the film music stars of the latest generation.

\section{Borsalino, the movie}

Once assembled and systematized all the above reflections, it does not take long to realize that one of the audiovisual texts most fitting to the present analysis happens to be also the best known of the whole bunch. Borsalino is a movie that encompasses nearly all the themes we have dealt with in the present essay. And, importantly, it is also a text that nearly everybody is familiar with, at least to some extent (as we shall see, that extent often corresponds to the soundtrack theme, which may even be better known than the movie as such). When it comes to Marseille-located films, only The French Connection rivals with Borsalino in terms of notoriety (unless, of course, one considers more recent and very successful movies, like 
the mentioned The Bourne Identity and Love Actually, which however had only few scenes placed in the French city).

The audience rewarded the movie with great commercial success all over the world (except, perhaps, the United States market, where Borsalino had less impact than the producers had hoped), and the critics, too, showed appreciation: still to this day it is very common to see the movie featuring in guides and suggestions of the "greatest gangster movies of all time" type. Well-known is also the story that Borsalino hats, an ever-present accessory in the two protagonists, experienced a true fashion revival after the film's release.

Borsalino, notoriously, is placed in 1930's Marseille. Two crooks with rather opposite personalities, the cold and meticulous Rocco Siffredi (yes: that other Siffredi chose his stage name after this character) and the instinctive and emotional Capella, despite an initial antagonistic meeting over a prostitute named Lola, decide to become partners in crime. They start by fixing gambling of boxing matches and horse races, and then expand into the more profitable business of fish and meat markets, entering in conflict with the main bosses of the city, Mr. Poli and Mr. Marello. While the latter two had managed to maintain a nonbelligerent equilibrium, sharing business and territory in a reciprocally-satisfying way, the ambition of the "new kids in town" Siffredi and Capella turns things upside down, resulting first in the killing of Mr. Marello and then of Mr. Poli. Acquired possession of the city, the two partners understand that their time will be soon done, as they will be now the targets of younger gangsters. Capella is the first to decide to leave, but an unknown, off-screen, hit man kills him. With his friend dead, Siffredi takes himself the decision to leave Marseille, ending thus the movie but leaving an open option for a sequel. Indeed, in 1974 Borsalino \& Co., Siffredi will return to Marseille after having found and executed Capella's killer, whose identity is revealed only in this sequel (a certain Francesco Volpone, brother of the new big boss of Marseille, Giovanni).

While heavily romanticized (in ways we shall later describe), the story of Siffredi and Capella is actually based on the real life characters Paul Carbone and François Spirito, two gangsters who dominated Marseille's "milieu" (literally "the underworld": the denomination of organized crime in France) roughly between the 1920's and the 1940's. Among the activities the two were involved in were prostitution, heroin traffic and most of all the membership in the Carlingue, an organization that cooperated with the Gestapo during WWII, in exchange for a laissez-faire of the German authorities over the criminal activities in Marseille. While the film references to Carbone and Spirito have a lot to do with time, place and certain relational dynamics in the partnership, the activities of the two fictional gangsters are morally "softer" than those of the real ones: with the possible exception of animal rights activists, most people would agree that making money with fixing horse races and controlling the meat/fish market are less contemptible crimes than prostitution, hard drug traffic and collaboration with the Nazis (the latter being a crime that film history has always treated with most severity), all directly related with the killing (or at least the exploitation) of human lives.

The reason for taking these liberties in the fictionalization of Carbone and Spirito are clear, and have a lot to do with the topics discussed in this essay.

On top of everything, of course, there is the above-mentioned "romanticization" of crime. While of course the Marseille pictured in Borsalino crawls with bad bad guys, the three 
protagonists, Siffredi, Capella and their "common girlfriend", the prostitute Lola (played by Catherine Rouvel), are at least likeable bad guys, they communicate and inspire sympathy, charm and humor - all features that would have been awkwardly out of tune with things like heroin traffic or collusion with Gestapo. Both Alain Delon and Jean-Paul Belmondo have of course built their whole career on playing "adorable scoundrels": "Certainly, critics have bracketed Delon and Belmondo together, especially for their work in thrillers $\langle\ldots$. . Theirs is indeed an image based on criminality" (Vincendeau, 2000, p. 159).

Borsalino was a project strongly wanted by Delon (who was the film producer as well) in order to have the opportunity to star with Belmondo. As the story goes, the collaboration turned out to be a clash of egos (surprise surprise), with Delon arguably setting the movie in such a way that he would look better, as a character, than Belmondo; the latter then demanding a contract that would ensure exactly the same amount of close-ups as his colleague (resulting in the production having to cut several sequences involving Delon), and - cherry on top - Belmondo suing Delon after his name as actor appeared under the inscription Alain Delon as producer in the film credits. What was at stake, evidently, was the predominance over the title of Jean Gabin's heir as "France's biggest movie star" (plus, possibly, that of "sex symbol of their generation"), which was by that time contended mostly by the two. What their vanity perhaps overlooked was that France was more than happy to welcome both of them in those roles, particularly in the light of their differences. As Ginette Vincendeau writes, "Delon and Belmondo redefined French stardom and offered parallel yet divergent visions of French masculinity" (2000, p. 158), with Belmondo externalizing his masculinity and Delon internalizing it. Borsalino was exactly the movie that celebrated this difference:
"The contrast is clear $\langle\ldots\rangle$ in the scene which brings the two stars together: Belmondo is playing billiards and fooling around when Delon appears as a silhouette through the cafe window. It is as if his beauty and presence were enough to signify his gangster identity as well as his virility. His appearance, his beauty, act as an armour and a spec- tacle sufficient to inspire awe" (Vincendeau, 2000, p. 180).

Or, as Kristiina Hackel puts it, "Delon is impeccable as the unsatisfied and increasingly sophisticated Siffredi; Belmondo is unflappable as the fun-loving and savvy, yet ultimately tragic figure of Capella" (2013, p. 42). Noteworthy is also the fact that Capella is most of the times wearing suits of warm colors like brown and beige, while Siffredi is often in grey or black. Besides these fire-and-ice archetypes of charm, the other obvious tool employed by Borsalino to enhance Delon's and Belmondo's stardom is the representation of their on-screen friendship, which once more is another strong expression of masculinity, as it is a relationship based on comradery and virility (let us not forget that their first encounter is a fistfight): "at the heart of the film is the story of their friendship and partnership and, more than any other caper crime, this is what we most want to succeed" (Hackel, 2013, p. 42).

Driven by the pleasantness of these two characters, plus, let us not forget, Lola and the other prostitutes (mostly characterized according to the Irma la Douce (director Billy Wilder, 1963)/Pretty Woman (director Garry Marshall, 1990) cliché that passes over in silence the darkest and most tragic aspects of prostitution), Borsalino's nostalgic, watercolor-painted take on a 1930's gangster story could not be a better fit for a city like Marseille. 
We also mentioned the theme of the difficult escape and/or return, and it is highly symbolic that Borsalino employs both at the two most strategic points of the story, the beginning and the end, assigning one to Delon and one to Belmondo. The movie indeed opens with a rather traumatic return: Siffredi has been released from jail and returns to the city to rejoin with his girlfriend Lola, only to find her with a new companion, Capella. Then, at the end of the movie, Capella decides to leave Marseille and announces it to his friend Siffredi with the fatalistic line "Chance... it does not exist" (in French: "La chance, ça n'existe pas"), implying that he was meant to leave at some point. However, as we know, he finds a more tragic exit, as he is shot by an unknown hit man outside a villa (as I mentioned already, it will only be the film's sequel, Borsalino \& Co., to reveal the killer's identity). As he dies in the arms of his friend, he pronounces the same line once more: "La chance, ça n'existe pas", this time implying that after all his destiny was a premature death. With his partner dead, it is now Siffredi who leaves Marseille, and as we have seen his return will be seen in the film's sequel (incidentally, it is another traumatic return, as it coincides with encountering and killing Capella's assassin).

The fatalism that animates Capella's decision is meant to communicate another important theme related to the characterization of Marseille: instability and transitionality, both in a factual and existential sense. Siffredi's and Capella's progressive ascension to the throne of the city's milieu is unrelenting and seemingly-unstoppable, yet they themselves perceive that the very factor that ensured their success - their hunger and ambition - is also the one that will eventually bring them down, as soon as a new hungry and ambitious mob will attempt the same climb. The fact that we do not get to see who kills Capella is precisely meant to underline that "someone new" (someone we do not even know) is now trying to take over the possession of the city. To leave Marseille at some point is thus something that has to happen, and, indeed, cannot be attributed to chance: Marseille's destiny is that nothing is forever and all is transitional, just like the harbor that so much typifies its landscape (and that is repeatedly visible in the film, particularly in the sequences of the fish market).

To conclude, while completely bypassing representatives of the NA communities, Borsalino puts a particular accent on the "Italian connection" within the milieu, as the readers will have already guessed by reading the surnames of the protagonists and the antagonists.

\section{Borsalino, the soundtrack}

Within this whole thematic and narrative framework, the film soundtrack, written and conducted by Bolling, seems like a match made in heaven. Not many know that the most important and memorable segment of the soundtrack, the main theme, was not written for the movie, but was simply chosen by the film production (including Delon himself, who was very instrumental in the decision) among several previously-written bits that Bolling drew to their attention. The particular one that was chosen had originally been written for a television (TV) commercial.

For this reason, the question we ask in this paragraph is not "what did Bolling do in order to have his music fit to the movie?", but rather "what did the production find in that theme that was so fitting to the movie?". Semiotically speaking, the difference is actually not so great, 
since signification is a process that does not necessarily require direct intentionality from the sender. As the hypothesis is that the soundtrack is extremely pertinent to the movie, our goal is to understand what is it (rather than "what was meant") that makes it so pertinent.

The soundtrack theme - we have briefly mentioned it - belongs to that particular Olympus of musical works whose level of fame has exceeded the movie they are meant to accompany, along with themes like Vangelis' for Chariots of Fire (director Hugh Hudson, 1981) and Malcom Arnold's for The Bridge on the River Kwai (director David Lean, 1957), or songs like Cole Porter's "Night and Day" (written in 1932) and Stevie Wonder's "I've just Called to Say I Love You" (written in 2002) (not to mention nearly every single theme/song appearing in movies stylistically-similar to Borsalino, which I shall later discuss).

By the time Borsalino was shot, Bolling was an accomplished jazz pianist who had played with international giants like Lionel Hampton and Kenny Clarke, and had already composed film scores for some ten years. From the mid 1960's, he had engaged into what became known as "traditional jazz revival", a stylistic trend that was attempting to revitalize the early years of jazz before the impetuous changes imposed by the bebop revolution. Bolling's creative approach to the revival was somewhat philological, as he had inaugurated, in 1966, a series of records meticulously devoted to some of the main genres of the first half of the 20th century, all marked with the adjective "original": Original Ragtime (released in 1966), Original Boogie Woogie (released in 1968), Original Piano Blues (released in 1969), Original Jazz Classics (released in 1970), Original Piano Greats (released in 1972).

Borsalino, released in 1970, came therefore in the very middle of this project, and so did the original television commercial theme (which was composed a little earlier): it is thus no surprise that a retro-nostalgic film like Borsalino is accompanied by an equally retro and nostalgic soundtrack. Ragtime, manouche, varieté, boogie, blues and tango are among the main stylistic references offered by Bolling's score, proving that he reversed on the film most of the artistic research he was pursuing on his own, via the mentioned recordings. Retro are also some important choices in arrangement, particularly the "easy listening" approach of the orchestra (much more entertainment - than virtuosity-oriented, exactly like jazz tended to be before bebop made it a primarily-intellectual experience), and the distinctive sound of honky-tonk piano - the lo-tech instrument by definition (for readers less familiar with the expression, honky-tonk is a style stemming from the sound of old, cheap and poorly-cared-for pianos, which had malfunctioning keys and tended to be out of tune. For such reasons, the type of music played on those pianos had more an accent on rhythm than melody or harmony).

Besides the historical placing of the movie and Bolling's personal creative path as an artist, there is a third important reason - I believe - for the evocative quality of the soundtrack, and it relates to what was going on in the mainstream cinema of those days. Borsalino, indeed, was not the only internationally-successful movie to present a romanticized view on crime (especially via true or semi-true stories from the past). Worth mentioning, in the same period, are at least John Schlesinger's Midnight Cowboy (1969), George Roy Hill's Butch Cassidy and the Sundance Kid (1969) and The Sting (1973), Sergio Leone's Once Upon a Time in the West (1968) and Duck, You Sucker! (1971 - although these two have probably more to do with the personal artistic path of Leone than with any general trend), Tonino Valerii's $M y$ Name Is Nobody (1973), and others. 
Now, besides presenting us with adorable (and very handsome) scoundrels like Robert Redford, Paul Newman, Terence Hill or Jon Voight, and besides making crime look fun and respectable, these movies sport a similar attitude towards soundtrack, engaging into a series of dewy-eyed scores, themes and songs that - as I briefly mentioned - to this day are arguably more popular than the whole movies. That is most certainly the case with Burt Bacharach's "Raindrops Keep Falling on My Head" (written in 1969, theme song for Butch Cassidy and the Sundance Kid), Harry Nilsson's "Everybody's Talkin"' (written in 1969, theme song for Midnight Cowboy), Ennio Morricone's "Sean Sean” (written in 1971, theme for Duck, You Sucker!, arguably the least known - and most unjustly underrated - installment of Leone's two trilogies), and most of all, in relation to Borsalino, the whole rediscovery of Scott Joplin's ragtime in The Sting, a movie that not by chance was nicknamed "the American Borsalino" by film critic Christopher Hudson, as it replicates on Deray's template in many ways: same temporal location, similar plot and themes, friendship story between - well - two male sex symbols, predominance of comedy tones, and so forth - plus indeed music.

On why this type of movies became so popular in that period, we can advance a few hypotheses. One that I find most convincing relates to the many changes that the 1960's brought to film authorship (and to the whole society, of course). Having to face a crisis of many traditional genres (including Western, musical, thriller, historical drama and many others), due in turn to the crisis of many traditional values (the 1960's witnessed the emergence of youngsters as social category, civil rights, women rights, sexual liberation, drug culture, historical revisionism, anti-moralism and so forth), filmmakers, especially from the late 1960's onwards, began exploring more possibilities for filmic communication and storytelling, offering, among others, different looks at history; more of character complexity and moral ambiguity; less of "studios" atmosphere and more of real locations; drier, more realistic camera work and a weaker type of narration ("weak" in Francesco Casetti's sense, as in "less intelligible"). The whole "American New Wave" movement, that originated exactly in the second half of the 1960's, was a direct consequence of this reform (Midnight Cowboy possibly being a quintessential example).

As it often happens, the whole soundtrack of Borsalino is centered around the main theme: plenty of the musical moments throughout the movie are simple re-elaborations of it, with few variations that do not threaten the recognizability of the famous melody. More distinctive fragments do exist, of course, but they all operate within the same musical context. The theme, at any rate, remains the most recognizable musical item of the movie, and is also the one that most effectively communicates the mood and the tones for the material displayed in the story. It is composed in $\mathrm{C}$ major with a more modulating attitude in the $\mathrm{B}$ section (which turns to F major, then operates a couple of steps towards E minor, and finally offers a last step in $\mathrm{G}$ major to return to the A section) and has an uncharacteristicallyregular structure A-A-B-A-A-B with no break or asymmetry whatsoever (a feature we shall discuss more in detail, later). Interestingly, it is played throughout the movie (and in the various versions) both as non-diegetic and diegetic music - the latter being a less typical occurrence for a soundtrack, and testifying - I believe - to the historical credibility of such music in a context like the one presented in the movie: the music sounds very much as if it was composed in the 1930's. 
Once we have discussed the nostalgic/retro character of the composition and its arrangement, we may also focus on other music-movie meaningful connections. The issue of "instability/transitionality", for instance, is also a relevant feature. The melody of the theme, indeed, is in C major and is set on a Lydian mode, starting exactly from the note that characterizes the latter ( $\mathrm{F} \#$ instead of a natural $\mathrm{F}$, that would be typical in the diatonic scale of $\mathrm{C}$ - see Figure 1). To do so in a melody means, among other things, to subtract solidity and firmness to it, because it basically corresponds to playing a tune based on a given tonic ( $\mathrm{C}$, in our case) but relying on the natural scale of the dominant $(G)$, which is notoriously the "dynamic" harmonic function, the one that gives the necessary tension that is eventually resolved on the tonic (via a cadenza, for instance). If we opt for a Lydian mode, it means we virtually create a co-existence between the tonic and the dominant, much to an "instability" effect.

Since we are talking about tension and resolution, a second element of instability occurs in correspondence of what in jargon is defined as "turn-around", that is, the transitional phrase that allows section B to return to A. It is a deceiving cadenza in four bars (in Figure 2 it starts where the arrow appears), that first neatly constructs the harmony in order to resolve on the E minor chord (via a rather typical F\#7-B7-Em path), then, just as the listener is content with the resolution, it adds an extra bar with a G7 chord that re-establishes tension, and asks instead to go to $\mathrm{C}$ major, which is - as we have seen - the tonality of section $\mathrm{A}$.

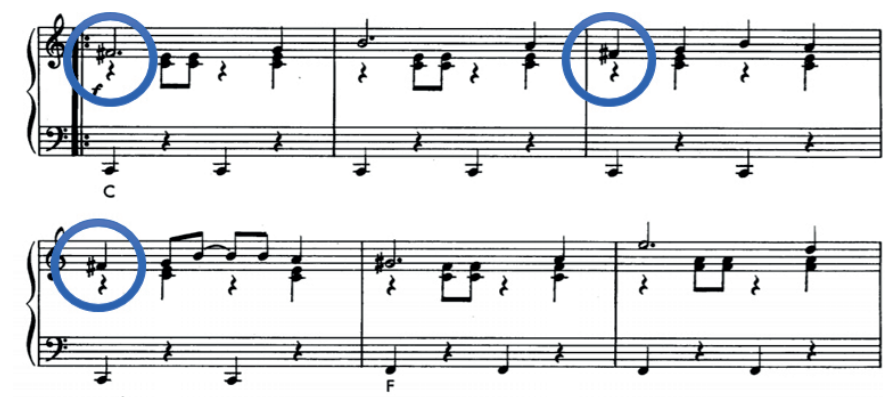

Figure 1. The Lydian notes in Borsalino's main theme (source: created by the author)

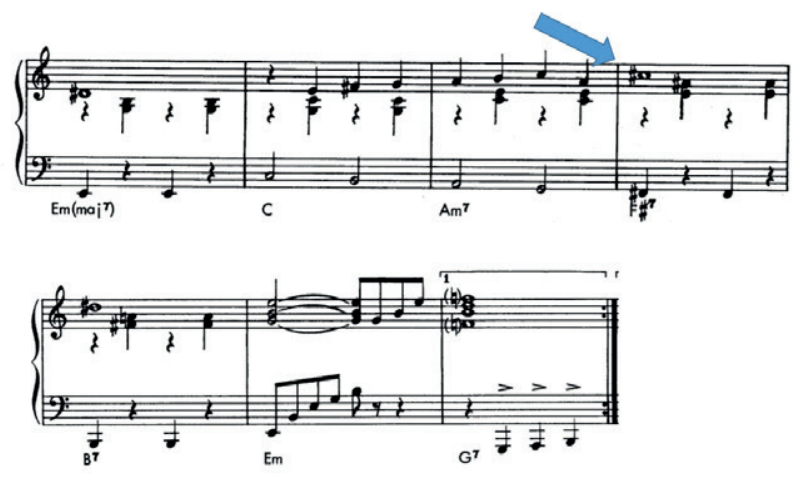

Figure 2. The deceiving cadenza for the turn-around from section B back to A (source: created by the author) 
This way, besides instability, the sensation one gets is also that of a strong circularity in a melody that - no matter what - must alternate A and B ("La chance, ça n'existe pas"), even when it looks that B would "prefer" going in another direction. A sense of circularity is also given by the melody of section A, which, for lack of more technical expressions, is very "carousellike" (anybody familiar with this theme will understand what I mean), while section B, due to both the melodic movement itself and to switch from tonic to dominant (from $\mathrm{C}$ to $\mathrm{F}$, that is), displays a brighter and airier feel, more in tune with the another important idea conveyed in the film, that of leaving/escaping. "Circular" is also the fact that, as we have mentioned, the structure of the theme is unusually regular: A, A, B, A, A, B. Although readers unfamiliar with music theory will not find anything strange in such tidy regularity, the thing is that structures of this kind are quite rare. There is always an element that breaks the regularity: an extra repetition of A or B, the appearance of a middle-eight, a solo part, a shortened version of one of the sections, a coda, etc. While I ignore the reasons why Bolling chose to be so symmetric, I would not be surprised if it turned out that this was still part of his "return to traditional jazz" program, as very early jazz, indeed, tended to display more regular structures.

One more note about how the theme blends with the idea of "romanticized crime": we have seen how the issue is addressed in a historically-conscious way (with the retro feel of both music and movie), and how that is mostly conveyed by stylistic choices in arrangement and genre. But there is more and that concerns the melody. There is hardly a doubt that the tune as such possesses an instantly-memorable and catchy quality, but it would be a mistake to assume that this is due to a certain compositional obviousness and to the recourse to melodic clichés. On the contrary, Bolling constructed his theme in that particular sophisticated way that only great tunesmiths like Bacharach, Andy Partridge or Paul McCartney can eventually make look "simple". We have already mentioned the employment of a Lydian mode (which already counts as one sophistication), but in reality that extra F\# is not the only unusual note in this charming melody. Jazz has of course accustomed us to the idea that a tonality is just a pretest to virtually hit any note one deems fit, but that was hardly Bolling's intent, here. Let us not forget that the French composer a) was after a very traditional idea of jazz (one, in other words, that is not madly keen on alienating concepts like scale and tonality), and b) had originally written this theme for a TV commercial, a task that - like film music and even more - requires attention-grabbing musical strategies of the most effective type, and certainly clever-clogs melodic obscurity is not among them.

What Bolling did, instead, is to paraphrase Edgar Allan Poe's famous quote, "the best place to hide is in plain sight": he placed all the unusual notes in the most audible spots of the melody (section A in particular), as "grounding notes", that is, notes of a greater length which the melody leans and rests on (see Figure 3). There, where everybody would have time and opportunity to notice that nearly none of them belong to the natural scales of the respective harmonic function (and those that belong should rather create tension, not rest), we get instead the result that no average listener finds them "weird".

Although I will not delude myself for a second that Delon (and eventually Belmondo) went any near a perception of this sort while selecting Bolling's theme, it is my conviction that these notes are exactly a (involuntary but not less effective) representation of Siffredi and Capella. They are "illegal" within the context of what we would normatively expect to hear 

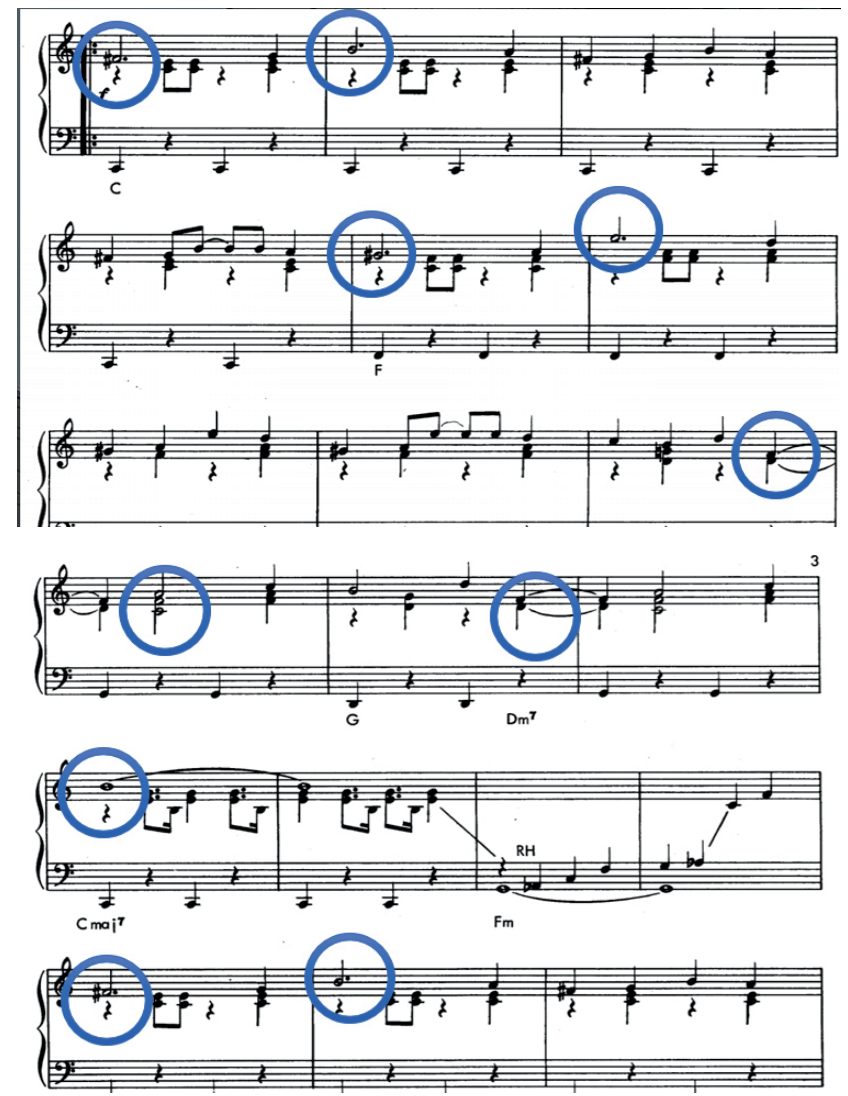

Figure 3. The "adorable scoundrel" notes in the section A of the theme (source: created by the author)

in a given harmonic context, and yet they define the theme more than anything else in it, proving to be extremely catchy choices. Illegal but catchy, naughty but likeable, these notes are the actual "adorable scoundrels" of the theme, and just like the two French actors, they "star" as protagonists in the melody.

\section{Conclusions}

This article discussed the modes and the typologies of audiovisual representations of the city of Marseille, with a particular attention for the musical strategies. A corpus of 120 movies (and some TVSs) was analysed, with the film Borsalino (both movie and soundtrack) employed as detailed case-study.

The following is a summary of the main findings and questions discussed:

- Crime, violence and illegality constitutes the most relevant topic/genre in the majority of the texts analyzed. Secondly, we find what we have called "Harbour/frontier topics": Marseille serves as context for stories of adventurers, sailors, desperados and renegades, who are often escaping from the law (or - more existentially - from their past), 
due to their involvement in some illegal activity. Thirdly, there are stories involving immigrant characters, NAs/Muslims and Italians in particular. Fourthly, we find love stories of the "cursed" type, hardly easy or happy, most of the times with a tragic element. Fifthly, there are war movies, particularly WWII movies, which tend to focus on the underground, clandestine resistance of French partisans against Nazi occupation.

- These five topics/genres can be crossed with a few thematic/narrative contexts that seem to frame the stories more often than others: the theme of the traumatic escape and/or difficult return, the fact that Marseille is most of the times a lo-tech city, the tendency to represent Marseille as a working class city, the tendency to "romanticize" and "soften" crime and illegality, and a certain sense of instability and transition (characters hardly "inhabit" or "settle" in this city: they rather arrive, return, leave, or dream of leaving, stay temporarily).

- There is no specific musical (stereotyped) authentication for Marseille: no given movie makes an attempt to "sound like Marseille", it is rather that Marseille is pictured as sounding like the particular type of movie it appears in. More often than not, that occurs in any of the following three ways: musical conventions dictated by this or that genre and/or this or that historical/geographical context, a particular inclination to recur to jazz, and the employment of "ethnic" elements, with a particular reference to NA musical cultures.

- Deray's Borsalino was chosen as a case-study as it is arguably the one movie that encompasses nearly all the themes analyzed in the article: "romanticization" of crime (the protagonists are good bad guys, designed to inspire sympathy, charm and humor); the theme of the difficult escape and/or return (Borsalino employs both at the two most strategic points of the story, the beginning and the end, assigning one to Delon and one to Belmondo); instability and transitionality, both in a factual and existential sense (the protagonists' progressive ascension to the throne of the city's milieu is seemingly-unstoppable, yet they perceive that their very ambition will be soon outdone by someone else's ambition); the presence of immigrant characters, in this case several with Italian origins.

- The film soundtrack, composed by Bolling, proved to be a perfect match for the movie: it is equally retro and nostalgic (with references to ragtime, manouche, varieté, boogie, blues and tango, with an "easy listening" approach of the orchestra, and with the employment of honky-tonk piano, the lo-tech instrument by definition); it addresses the issue of "instability/transitionality" (via the employment of a Lydian mode, and a deceiving cadenza on the "turn-around"); it blends with the idea of "romanticized crime", by placing what we have called here "adorable scoundrel" notes: grounding notes in the melody that are in principle out of context when reasoning in traditional terms of tonality and scale, but nevertheless are strategically placed to sound pleasant and sympathetic, just like the good bad guys of the movie.

\section{References}

Blanc-Hoàng, H.-S. (2013). Marseilles melting pot: immigrants, refugees and stateless characters. In M. Block (Ed.), World film locations: Marseilles (pp. 88-105). Series: World Film Locations Series. Bristol: Intellect Books.

Block, M. (Ed.). (2013). World film locations: Marseilles. Series: World Film Locations Series. Bristol: Intellect Books. 
Bohler, O. (2013). The underworld is in his lands': Marseille gangster films. In M. Block (Ed.), World film locations: Marseilles (pp. 48-67). Series: World Film Locations Series. Bristol: Intellect Books.

Hackel, K. (2013). Borsalino. In M. Block (Ed.), World film locations: Marseille (p. 42). Series: World Film Locations Series. Bristol: Intellect Books.

Lioult, J.-L. (2013). The old port and the canebière. In M. Block (Ed.), World film locations: Marseilles (pp. 28-41). Series: World Film Locations Series. Bristol: Intellect Books.

Lynch, K. (1960). The image of the city. Cambridge, MA: MIT Press.

Martinelli, D. (2016). Arts and humanities in progress: A manifesto of numanities. Numanities - Arts and Humanities in Progress. Vol. 1. Berlin/New York: Springer International Publishing AG. https://doi.org/10.1007/978-3-319-45553-2

Martinelli, D. (2010). Authenticity, performance and other double-edged words: essays on popular music. Helsinki/Imatra: International Semiotics Institute.

Prime, R. (2013). Marcel Pagnol's Marseilles: Marius, Fanny, César. In M. Block (Ed.), World film locations: Marseilles (pp. 8-27). Series: World Film Locations Series. Bristol: Intellect Books.

Schweinhardt, P., \& Gall, J. C. (2014). Composing for film: Hanns Eisler's lifelong film music project. In D. Neumeyer (Ed.), The Oxford handbook to film music studies (pp. 131-187). New York, NY: Oxford University Press. https://doi.org/10.1093/oxfordhb/9780195328493.013.023

Vincendeau, G. (2000). Stars and stardom in French cinema. London and New York: Continuum.

Yanow, S. (2004). Jazz on film: the complete story of the musicians \& music onscreen. San Francisco, CA: Backbeat Books.

\section{AUDIOVIZUALUMAS IR MARSELIO (PRANCŪZIJA) MIESTAS: KŪRYBIŠKUMAS, KOMUNIKACIJA, REPREZENTACIJA}

\section{Dario MARTINELLI}

\section{Santrauka}

Marselis minimas filmuose Pavojingas miestas (režisierius Peteris Makas, 1992), Namas ant jūros kranto (režisierius Edmond'as T. Gréville's, 1955), Prancūziškas ryšys (režisierius Williamas Friedkinas, 1971) ir, žinoma, Borsalino (režisierius Jacques'as Deray, 1970). Iki šiol rodomas Netflixo serialas (kūrejjas Danas Franckas, 2016-2018). Naršant internete ir ieškant pačių svarbiausių Marselio audiovizualinių reprezentacijų pavadinimų, krinta į akis tai, kad šis miestas komunikuoja kai kuriuos pasikartojančius topoi: pasienio miestas, pačios nelegaliausios veiklos, banditų, jūreivių, nuotykių ieškotojų ir prostitučių daugiaetnès bendruomenės apgyventa vieta. Jos gyventojams dažnai būdingas didelis žavesys ir patrauklumas. Šiame straipsnyje, remiantis kino studijų, muzikologijos, kūrybiškumo studijų ir komunikacijos studijų teorijomis bei metodologijomis, siekiama pabrèžti reikšmių įvairovę, kurią perteikia tiek vizualiniai, tiek muzikiniai šaltiniai. Kaip atvejo tyrime, straipsnyje susitelkiama ị Borsalino, kuris yra bene pats garsiausias filmas, nufilmuotas Marselyje. Tai filmas su žymiu garso takeliu (kurị sukūrè džiazo kompozitorius Claude’as Bollingas). Abiem atvejais tobulai, kaip teigiama, sujungiami pirmiau minèti topoi.

Reikšminiai žodžiai: audiovizualinẻ komunikacija, Borsalino, Marselis, muzikologija, filmo muzika, kino studijos, semiotika. 